\title{
Technological, economic and social aspects of the provision of solid fuels to the Arctic regions of Yakutia
}

\author{
Sergye Tkach $^{1}$, Natalya Batugina ${ }^{1 *}$, Vladimir Gavrilov ${ }^{1}$ \\ ${ }^{1}$ Chersky Institute of Mining of the North Siberian Branch Russian Academy of Sciences, Laboratory \\ of the Problems of the Rational Use of Mineral Resources, 677980, Yakutsk, Russia.
}

\begin{abstract}
The article examines the reasons leading to the increase in the price of fuel and energy resources consumed in the Arctic regions of the Yakutia. The paper studies the conditions for the development of coal deposits in the region. It is shown the lack of open cast mines that meet modern criteria for efficient use of small-scale open mining by quality and logistic accessibility. This article determines that with the minimum level of clogging of the hard coal mined and the stabilization of its quality over time, it is possible to efficiently recycle the fuel without other precombustion measures. In the case of development of brown coal deposits, additional enrichment is required after extraction to improve the level of consumables. The paper stresses that development of local small-scale deposits of coal is important direction to improve energetic safety of arctic regions. It is necessary to select the coal mines most suitable for open-cast mining, as close to consumers and also with the best quality indicators. The use of the specified measures of technological and economic management, administrative regulation and improvement of mechanisms of «northern delivery» make it possible to facilitate the creation and operation of new coal mines in the Arctic zone of Yakutia. In turn, this reduce coal delivery periods, its quantity and quality losses in the supply chain, and improve local fuel and energy complexes.
\end{abstract}

\section{Introduction}

Conditions for delivery of fuel and energy resources to the arctic regions of Republic Sakha (Yakutia) can be called super complicated: very low level of territorial development, low density of population, long distances to consumer (up to 2-3,000 km), complicated and long logistics (several crossings and delivery times of up to 2.0-2.5 years), limited transport time by water and road with small quantities of fuel consumed (5-50,000 tons) of regions.

Collectively, this results in significant losses and increases in the cost of fuel at the point of consumption by 3 to 8 times or more than the reference price at the place of shipment. In 2020, according to data available from the Regional Economy Commission, Republic of Sakha (Yakutia), the cost of coal makes considering the delivery to regions is 3.5 to 25 thousand rubles per ton.

\footnotetext{
${ }^{*}$ Corresponding author: batuginan@mail.ru
} 
In the most inaccessible areas, the coal itself represents only $15-20 \%$ of the cost structure, while in the other Arctic areas it represents 37-50\%. The exception is the Verkhnekolymsky region - about $78 \%$ (mining takes place in this region). Logistics costs increase the price of coal so much that it is potentially possible to develop coal deposits efficiently in locations close to major consumption points, because of the potential for reducing the cost of northern delivery and improving the energy security of the territories.

In the Strategy for Development of the Arctic Zone of the Russian Federation, it is proposed to optimize the economic mechanisms of «northern delivery» including, «by using local energy sources, energy-saving technologies». Development of local coal deposits is one of the potentially efficient uses of the region's mineral resources. But this requires taking into account a wide range of socio-economic, natural-climatic, georesource, technological, energy and other factors.

\section{Theory}

The analysis shows that coal exploration in the Yakutia region was mainly carried out in the 1940-1960s. Many coal shows have been identified, 20 coal deposits (14 hard coal, 6 brown) are placed on the State Balance of Russian Mineral Reserves. Their balance sheets at the beginning of 2012 were 432.9 million tonnes in categories $\mathrm{A}+\mathrm{B}+\mathrm{C}_{1}$, and 199.3 million tonnes in category $\mathrm{C}_{2}$. Hard coal accounted for 398 million tons and 194 million tons, brown 35.2 million tons and 5.6 million tons, respectively [1].

Only one coal company is in the region - open-pit «Zyransky» (150-200 thousand tons per year). Coals represent by various ranks from lignite to hard coal and have wide range of quality characteristics. 17 deposits are listed in the unallocated subsoil fund, 3 deposits in the distributed one (Nadezhdinskoye coal deposit, subsoil user Zyryansky coal mine; Taimylyrskoye coal and boghed deposit, winner of the auction JSC «Arctic uglesintez», 2014; Kularskoye brown coal, winner of the auction JSC «Prognoz-Serebro», 2020).

Under the existing schemes for the delivery of goods to the Abyisky, Allayhovsky and Moma regions, located in the basin of the navigable river Indigirka, Ust-Jansky and Verkhoyansky, situated in the basin of the navigable river Yana, are among the most difficult to reach.

Analysis of the economic, geographical and geological indicates that the Tikhon, which is more suitable for underground work, and the Krasnorechensk hard coal deposits are located in close proximity to the first group of areas.

The Krasnorechensky deposit has the highest level of readiness for exploration according to geographical and geological conditions and is located in the immediate vicinity of the main transport corridor - river Indigirca. Lignite coals of Kular and Uyandinsky deposits are of relatively low quality. At the same time, there is a total insufficient coal reserves available for open pit mining.

The study of the qualitative characteristics of coal from the main deposits showed that hard and soft coals are suitable for combustion with a sufficiently high level of efficiency without preliminary fuel preparation and modernization of boiler equipment. Coals from the Krasnorechenskoye and Tikhonskoye deposits meet the requirements of consumers for the quality of coals (Table 1).

The development of brown coal deposits in Uyandsky and Kular regions with high working humidity, ash content and associated low combustion heat requires more detailed feasibility studies, including the feasibility of additional operations to prepare coal for efficient combustion, medium and long-term storage.

The latter is due to the fact that lignits are quickly oxidized in the open air which results in a reduction in their thermal properties, a change in the grain size towards an increase in the yield of small size classes during mining and storage [2]. This, requires the 
development of technological and organizational measures aimed at preserving and improving the natural properties of coal and reducing the negative impact of mining and environment. The latter is explained by the fact that lignites are oxidized rapidly in the open air, which results in a decrease in their thermal properties, a change in the grain size towards an increase in the yield of small size classes during mining and storage [2]. This, in turn, requires the development and implementation of special technological and organizational measures aimed at preserving and improving the natural properties of coal and reducing the negative impact of mining on the environment.

Table 1. Coal quality of deposits

\begin{tabular}{|c|c|c|c|c|c|}
\hline $\begin{array}{l}\text { Coal deposit, type } \\
\text { and grade }\end{array}$ & $\begin{array}{l}\text { Mass fraction } \\
\text { of working } \\
\text { moisture } \mathrm{W}_{\mathrm{t}}^{\mathrm{r}} \text {, } \\
\% \text { average / } \\
\text { limit }\end{array}$ & $\begin{array}{c}\text { Ash } \\
\text { content } \mathrm{A}^{\mathrm{d}} \\
\% \text { average/ } \\
\text { предельна } \\
\text { я }\end{array}$ & $\begin{array}{c}\text { volatile } \\
\text { yield, } \\
\mathrm{V}^{\text {daf }} \%\end{array}$ & $\begin{array}{l}\text { gross calorific } \\
\text { value } \\
\mathrm{Q}_{\mathrm{s}}{ }^{\text {daf }}, / \text { inferior } \\
\mathrm{Q}_{\mathrm{i}}^{\mathrm{r}}, \mathrm{kcal} / \mathrm{kg}\end{array}$ & $\begin{array}{c}\text { mass } \\
\text { fraction of } \\
\text { sulphur, } \mathrm{S}_{\mathrm{t}}{ }^{\mathrm{d}} \text {, } \\
\%\end{array}$ \\
\hline $\begin{array}{l}\text { Dzhebariki-Haya, } \\
\text { hard coal }\end{array}$ & $10,0 / 12,0$ & $17,0 / 25,0$ & 41,3 & $7500 / 5200$ & 0,3 \\
\hline $\begin{array}{l}\text { Krasnorechenskoye, } \\
\text { «Sogolokh», hard } \\
\text { coal }\end{array}$ & $-/ 16,0$ & $18,0 / 23,0$ & 42,0 & $7000 / 5286$ & 0,8 \\
\hline $\begin{array}{l}\text { Tikhonskoe, hard } \\
\text { coal }\end{array}$ & $10 /-$ & $13,6 /-$ & - & $7069 / 5200$ & 0,6 \\
\hline $\begin{array}{l}\text { Nadezhdinskoe, soft } \\
\text { coal }\end{array}$ & $8,0 / 10,0$ & $19,0 / 21,0$ & 35,0 & $8300 / 6100$ & 0,4 \\
\hline Kular, lignite & $40,1 /-$ & $33,94 / 55,7$ & 59,76 & $6359 / 3360$ & 0,1 \\
\hline Uyandinskoe, lignite & $50 / 55,1$ & $23,8 / 27,0$ & $57,9-63,6$ & $6050 / 1930$ & 0,3 \\
\hline
\end{tabular}

It should also be taken into account that ensuring the high reliability of coal supply in hard-to-reach, transport and energy isolated regions requires the creation of a higher (one to four years) level of coal reserves in the storages (the duration of storage from one to three years) which is inefficient [3].

Krasnorechensk deposit is located on the specially protected natural territory of local importance - resource reserve «Zasieversk» of Abyisky region. The main task of the reserve is to preserve it as a place of reproduction of fish stocks (arctic omul), habitat of rare objects of flora and fauna. According to the official documents, in the vicinity of the deposit in 1812-1854 a smallpox epidemic was recorded. Because of this, before the start of mining operations at the deposit, it is recommended to conduct special scientific research aimed at updating information about the danger of environmental contamination by pathogens of this disease.

One of the main principles of the rational use of local coal in the Arctic regions of the Republic of Sakha (Yakutia) is that for developing local deposits it is required to use selectively the best areas for open pit mining, lying at shallow depths, located near potential consumers, having reserves with the best quality and environmental requirements [4].

In 2020, 63.5 thousand tons of coal from the Dzhebariki-Khaya mine and 99.5 thousand tons from JSC Zyryanskiy coal mine import to the Arctic regions of the Republic of Sakha (Yakutia) for the needs of housing and communal services, 3.8 thousand tons of Arkagala coal from the Magadan region (about $300 \mathrm{~km}$ along the Kolyma road and $150 \mathrm{~km}$ along the Indigirka river). For the needs of JSC Sakhaenergo (Deputatskay ETFs) and AO «Teploenergoservice», 30 thousand tons of coal, from other deposits were supplied (table $2)$. 
Table 2. Shipment of coal to the polar regions of Yakutia for the needs of housing and communal services in 2016-2020, thousand tons

\begin{tabular}{|l|l|l|l|l|l|}
\hline \multicolumn{1}{|c|}{ region consumer / supplier } & \multicolumn{1}{c|}{2016} & \multicolumn{1}{c|}{2017} & \multicolumn{1}{c|}{2018} & \multicolumn{1}{c|}{2019} & \multicolumn{1}{c|}{2020} \\
\hline Zhiganskiy & 24,5 & 23,6 & 25,7 & 20,4 & 20,0 \\
\hline Verkhoyanskiy ${ }^{1}$ & 61,6 & 64,4 & 66,8 & 60,6 & 61,2 \\
\hline Ust-Yanskiy & 35,4 & 34,8 & 33,1 & 30,4 & 32,5 \\
\hline Abyiskiy & 13,6 & 13,5 & 15,7 & 14,7 & 15,0 \\
\hline Momskiy & 4,3 & 4,4 & 4,6 & 6,3 & 7,4 \\
\hline Verkhnekolymskiy & 29,2 & 26,1 & 26,5 & 25,7 & 25,1 \\
\hline Srednekolymskiy & 31,2 & 29,0 & 29,8 & 32,1 & 32,6 \\
\hline Nizhnekolymskiy & 5,7 & 5,1 & 5,3 & 19,3 & 19,4 \\
\hline Total & 205,4 & 200,9 & 207,5 & 209,5 & 213,2 \\
\hline Open-pit Dzhebariki-Haya & 121,4 & 122,8 & 125,6 & 81,1 & 63,5 \\
\hline Open-pit Zyryanskiy & 82,1 & 76,2 & 79,8 & 94,1 & 95,8 \\
\hline Open-pit Arkagalinskiy & 1,9 & 1,9 & 2,1 & 3,9 & 3,8 \\
\hline others & - & - & - & 30,4 & 50,2 \\
\hline
\end{tabular}

${ }^{1}$ Source: data of Regional Economy Commission, Republic of Sakha (Yakutia). In 2019, coal is delivered to the Verkhoyansk region from the Kadykchanskiy coal mine (13 thousand tons) and 17 thousand tons and from the city of Murmansk (the company JSC Russian Coal)

However, the cost of coal at the place of consumption, taking into account transportation and storage, is increasing, as shown by the example of the Leno-Yanskiy region (fig. 1). In 2020 the cost of coal is vary from 3.6 thousand rub./t (Verkhnekolymskiy) to 24 thousand rub./t (Verkhoyanskiy). Since 2019, coal has been imported into Ust-Yanskiy region from the Kadykshanskiy coal open-pit (Magadansky region). The cost of coal at the place of its consumption is 16 thousand rubles per ton (to compare the cost of coal from Dzhebariki-Haya - 23 thousand rubles per ton.

\section{Results and discussion}

In world practice, small mining companies, including artisanal ones, are widely used in coal mining. The experience of such companies (USA, China, India, Pakistan, Mongolia, etc.) shows that they can be opened where large companies are not interested in mining because of the small scale of production. The experience of such companies (USA, China, India, Pakistan, Mongolia, etc.) shows that they can be opened in order to meet local needs in hard-to-reach areas by exploiting selected deposits. In developing countries, mining is done using rudimentary techniques, sometimes using manual labor. For example, in the mountainous regions of Pakistan, mining is carried out exclusively by small-scale companies [5]. For the Arctic regions of the Russian Federation this experience is completely difficult to apply: the legislation requires a number of permits and project documents, without which mining cannot be organized, even if the site is small and has no industrial value. For the Arctic regions of the Russian Federation this experience is completely difficult to apply: the legislation requires a number of permits and project documents, without which mining cannot be organized, even if the site is small and has no industrial value. Unincorporated mining for own use in Russia is prohibited. 


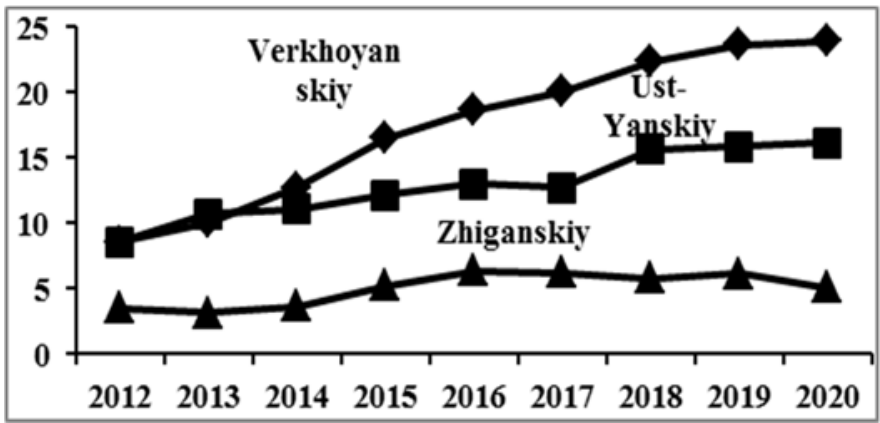

Fig. 1. Cost of coal including transportation and storage in the Leno-Yang districts in 2012 -2020 , thousands of rub/tons

When deciding to develop a small mine in the Arctic, the question is whether to establish a new low-capacity local plant or to leave decades-old and energy supply delivery schemes centralized and controlled by the executive, conditional tendering of suppliers? The main reasons for the decision to establish are to increase the energy security of the territory of residence and economic activity, to reduce social tension by reducing the risk of disruption of fuel supply for shallow rivers, the elimination of which implies the need to attract significant additional funds (in recent years about 500 million rub. and more). The work of local mining companies providing coal to consumer in the enclosed areas make it possible: reduce the delivery time of coal by 1-1.5 years; increase the energy value of the coal used by $10-20 \%$ due to the reduction of losses, reduce the cost of early coal delivery budget to 1.5-1.6 times [4]. However, the price of coal produced at small local cuts must maintain an acceptable level of commercial benefit. In some cases, it may be higher than the cumulative criteria used (low production volumes, high start-up costs, cost of attracting skilled personnel, low initial demand due to the change in the type of fuel used, reconstruction of boiler rooms). Consider in more detail the impact of logistics conditions on the final price of coal.

The calculations carried out show that the cost of coal at various deposits in arctic zone of Yakutia is or can be at the level of 2.6-5.2 thousand rubles per ton (table. 3). A comparison of possible delivery schedule of coal by road transport from deposits in the basins of the Indigirka and Yana rivers to consumers at a distance of 200-800 km shows an increase of costs per ton of coal by 6.0-17.4 thousand rubles.

Even if the cost of coal in the development of new deposits in the immediate vicinity pf major consumption points equals the value of imported coal, energy security comes first which is significantly increased by improving the transport accessibility of fuel and energy resources. This approach is valid and consistent with market economy principles.

Rational selection of coal area for priority mining is one of the main tasks in the development of new deposits. Further study of the mineral resource base is required after preliminary expert selection.

This is due to the fact that the calculation of restrictions, the evaluation of mineral reserves was performed long ago according to the currently obsolete criteria. Technique and technology for coal mining, production and consumption have changed significantly in recent years. The quality requirements for these technologies have changed. 
Table 3. Comparison of the local cost of coal from different deposits

\begin{tabular}{|c|c|c|c|c|c|}
\hline \multirow[b]{3}{*}{ Indicators } & \multicolumn{3}{|c|}{ Hard coal } & \multirow{2}{*}{\multicolumn{2}{|c|}{$\begin{array}{r}\text { lignite } \\
\text { g, road transport }\end{array}$}} \\
\hline & \multirow{2}{*}{$\begin{array}{c}\text { open-pit } \\
\text { Dzhebariki- } \\
\text { Khaya, (river } \\
\text { delivery to } \\
\text { Verkhoyansk } \\
\text { region) }\end{array}$} & \multicolumn{2}{|c|}{ Deposit, open-cast mining, road transport } & & \\
\hline & & $\begin{array}{l}\text { Krasnorec } \\
\text { henskoe }\end{array}$ & Tikhonskoe & Kular & $\begin{array}{l}\text { Uyandin } \\
\text { skoe }\end{array}$ \\
\hline Delivery distance, $\mathrm{km}$ & 2800 & $200-800$ & $200-800$ & $300-00$ & $300-800$ \\
\hline Capex, million rub & - & $300-350$ & $350-434$ & - & $300-400$ \\
\hline $\begin{array}{l}\text { Стоимость добычи (цена), } \\
\text { тыс. руб./т (excl. VAT) }\end{array}$ & 2,6 & 4,5 & 5,2 & 5,0 & 5,0 \\
\hline $\begin{array}{l}\text { Стоимость доставки, } \\
\text { хранения, тыс. руб./т } \\
\text { (excl. VAT) }\end{array}$ & 25,9 & $7,0-17,4$ & $6,0-13,5$ & $6,5-12,6$ & $6,5-14,7$ \\
\hline $\begin{array}{l}\text { Cost of coal at the place of } \\
\text { consumption, thousand rub. } \\
\text { per ton }\end{array}$ & 28,5 & $11,5-21,9$ & $11,2-18,7$ & 16,6 & 18,2 \\
\hline
\end{tabular}

Special preferences are appropriate for coal companies operating or planning to mine in the Arctic. These may include: a tax rate of 0 per cent on mining; exemption from taxes on profits and assets of the companies; provision of State guarantees for loans for investment projects; subsidization of part of the cost of interest on them; cancellation of start-up payments on subsoil. Support for such companies is possible and need at the regional level, similar to subsidies of farm ones.

Administrative measures to facilitate the creation of small-scale coal mines are: simplification of the procedure for drawing up and agreeing on the authorization documents (use of forest areas and water resources, various expert examinations, connection to the infrastructure if there is one), which now includes between 18 and 40 approvals; many of which need to be renewed or updated annually.

The proposed support measures for the creation of coal mines in the Arctic zone are under the responsibility of the federal, republican and local authorities, and most can be solved with substantial amendments to federal legislation.

\section{Conclusions}

A comprehensive analysis of the conditions for the development of coal deposits in the Arctic regions of Yakutia shows that, despite the large reserves, in accordance with modern requirements for the quality of solid fuel and the level of rationality of possible logistics schemes, not enough.

The study of the quality indicators of the coal deposits in the region shows that their effective utilization by modern technologies without enrichment is possible for the Krasnorechenskiy and Tikhonskiy deposits in Indigirka.

Development of high-humidity and low-thermal brown coal deposits in Uyandi and Kularski and other deposits requires additional preparation for combustion after extraction to improve quality, briquetting, enrichment or gasification, which increases the cost of consumption.

The development of local coal deposits, as one of the way to improve the energy security of the Arctic regions of Yakutia and to support their social and economic development, should begin with the most suitable open-pit mines which are as close as possible to consumers and have the best quality indicators.

The use of the specified measures of geotechnological and economic management, administrative regulation and improvement of the mechanisms of «northern delivery» make 
it possible to facilitate the creation and operation of new coal mines in the Arctic zone of the Yakutia. This, in turn, can and should lead to shorter lead times from mining to coal consumption, reduce fuel losses in quantity and quality, simplification of transport and storage schemes for coal, improvement of local fuel and energy systems.

The reported research was funded by Russian Foundation for Basic Research and the government of the region of the Republic Sakha (Yakutia), grant № 18-45-140048 p_a

\section{References}

1. Coal Base of Russia. Vol. V. Book 2: Coal basins and deposits of the Russian Far East (Republic of Sakha, North-East, Sakhalin, Kamchatka). M. (1999)

2. V.L. Gavrilov, Ю.А. Хохолов, V.I. Fedorov, Fundamental and Applied problems of mining, 6(3), 219-225 (2019)

3. Zakharov, V.E., Kozlov, A.N., Donskoy, I.G. Proceedings of the RAS. Energetics, 6, 132-141 (in Russian) (2018)

4. S.M. Tkach, V.L.Gavrilov, N.S. Batugina, V.I. Fedorov, Fundamental and Applied problems of mining, 1(1), 79-85 (2014)

5. J. Laurance, International Journal of Coal Geology, 60(2-4), 117-150 (2004) 